\title{
Activin A stimulates catecholamine secretion from rat adrenal chromaffin cells: a new physiological mechanism
}

\author{
Damien J Keating and Chen Chen \\ Prince Henry's Institute of Medical Research, Clayton, Australia \\ (Requests for offprints should be addressed to C Chen, Prince Henry's Institute of Medical Research, P O Box 5152, Clayton, Victoria 3168, Australia; \\ Email: chen.chen@phimr.monash.edu.au)
}

\begin{abstract}
Activin $\mathrm{A}$ is a member of the transforming growth factor- $\beta$ family and has known roles in the adrenal cortex, from which activin A is secreted. We aimed to find whether activin $\mathrm{A}$ induces secretion of catecholamines from chromaffin cells of the adrenal medulla, which neighbours the adrenal cortex in vivo. Using carbon fibre amperometry, we were able to measure catecholamine secretion in real-time from single chromaffin cells dissociated from the rat adrenal medulla. Activin A stimulated catecholamine secretion in a rapid and dose-dependent manner from chromaffin cells. This effect was fully reversible upon washout of activin A. The minimum dose at which activin A had a maximal effect was $2 \mathrm{nM}$, with an $\mathrm{EC}_{50}$ of $1 \cdot 1 \mathrm{nM}$. The degree of secretion induced by activin $\mathrm{A}$
\end{abstract}

(2 nM) was smaller than that due to membrane depolarization caused by an increase in the external $\mathrm{K}^{+}$concentration from 5 to $70 \mathrm{mM}$. No response to activin A was seen when $\mathrm{Ca}^{2+}$ channels were blocked by $\mathrm{Cd}^{2+}$ $(200 \mu \mathrm{M})$. We conclude from these findings that activin A is capable of stimulating a robust level of catecholamine secretion from adrenal chromaffin cells in a concentrationdependent manner. This occurs via the opening of voltage-gated $\mathrm{Ca}^{2+}$ channels, causing $\mathrm{Ca}^{2+}$ entry, thereby triggering exocytosis. These findings illustrate a new physiological role of activin A and a new mechanism in the control of catecholamine secretion from the adrenal medulla.

Journal of Endocrinology (2005) 186, R1-R5

\section{Introduction}

Activins belong to the transforming growth factor- $\beta$ (TGF- $\beta$ ) superfamily of cytokines. Members of the TGF- $\beta$ family are important in a variety of biological functions including cell proliferation and death, homeostasis, differentiation, metabolism, immune responses and endocrine function (Harrison et al. 2005) and are required for the normal growth and function of a multitude of different tissues (Bilezikjian et al. 2004). Alterations or disruptions in the function of members of the TGF- $\beta$ family result in several types of cancers, fibrotic disorders of the liver, kidney and other organs as well as various inflammatory disorders (Massague 1998).

Activins have roles in regulating pituitary and reproductive function, controlling, for example, the production of pituitary follicle-stimulating hormone (FSH) (Massague 1998). Activin A is a member of the activin family and is a dimer composed of two activin $\beta A$-subunits. Apart from the classical role of activins in reproductive control, activin A has also been shown to effect ion channel function in different endocrine tissues. Activin A is located in insulincontaining human pancreatic $\beta$-cells (Wada et al. 1996) and increases insulin secretion in the presence of glucose in human pancreatic islets (Florio et al. 2000). Activin A closes $\mathrm{K}_{\text {ATP }}$ channels and increases $\mathrm{Ca}^{2+}$ channel amplitude in HIT-T15 insulinoma cells, resulting in membrane depolarization and $\mathrm{Ca}^{2+}$ entry (Mogami et al. 1995). Activin A also stimulates FSH secretion by causing membrane depolarization and the opening of $\mathrm{Ca}^{2+}$ channels in human FSH-secreting tumor cells (Takano et al. 1992, Takano et al. 1994). Neuronal survival of rat hippocampal cultures is also promoted by activin A and this effect is blocked by $\mathrm{Ca}^{2+}$ channel antagonists (Iwahori et al. 1997).

Activin signalling components are expressed in the adrenal cortex and activin A reduces secretion of several steroid hormones from this tissue (Vanttinen et al. 2003). mRNA for activin A and its receptor has been identified in human fetal and adult adrenal cortical cells and cultured adrenocortical cell lines, and adrenocorticotrophin induces secretion of activin A from these cell types (Vanttinen et al. 2002). The adrenal cortex is located within the adrenal 
gland, a tissue that also contains the adrenal medulla. The primary function of the adrenal medulla is catecholamine synthesis and secretion, which is carried out by chromaffin cells. Activin A and its receptors are expressed in human pheochromocytomas, a form of adrenal medullary tumor, and production of activin $\mathrm{A}$ in cultured pheochromocytoma cells is induced through the protein kinase A pathway (Liu et al. 2000).

Although activin A is known to stimulate hormone secretion from several endocrine tissues, activin signalling components are present in the adrenal gland and activin A is secreted from the adrenal cortex, it remains unknown whether activin A effects catecholamine secretion from neighbouring adrenal medullary chromaffin cells. We present in this report the first evidence that catecholamine secretion from single rat chromaffin cells can be stimulated by activin $A$. This represents a previously undiscovered physiological pathway involving an important signalling molecule regulating the secretion of a hormone which has widespread homeostatic influences.

\section{Materials and Methods}

Adult male Wistar rats were killed by carbon dioxide inhalation as approved by the Monash Medical Centre Animal Care Committee. After they were removed, 4-6 rat adrenal glands had their adrenal capsule and cortex dissected away in cold calcium-free saline (Locke's buffer). Locke's buffer consisting of $(\mathrm{mM}): \mathrm{NaCl}, 154 ; \mathrm{KCl}, 5 \cdot 6$; $\mathrm{NaHCO}_{3}, 3 \cdot 6$; glucose, 5.6; HEPES, 5.0; pH 7.4. The remaining adrenal medulla tissue was then incubated with collagenase (Collagenase type A, Roche) in Locke's buffer at a concentration of $3 \mathrm{mg} / \mathrm{ml}$, in a shaking bath at $37^{\circ} \mathrm{C}$ for 15,10 , and $5 \mathrm{~min}$. The tissue was triturated between incubations. The collagenase was then diluted further in cold Locke's buffer centrifuged at $2 \boldsymbol{g}$ for $5 \mathrm{~min}$. After centrifugation, cells were resuspended in Dulbecco's modified Eagle's medium (Thermo Electron, Melbourne, Victoria, Australia) supplemented with 1\% penicillin/ streptomycin (Invitrogen) and 10\% FCS (JRH Biosciences, Lenexa, KS, USA) and the resuspended material was filtered through a nylon mesh. Cells were then centrifuged at $200 \boldsymbol{g}$ for $5 \mathrm{~min}$, resuspended and plated on $35 \mathrm{~mm}$ culture dishes and incubated at $37^{\circ} \mathrm{C}$ with $10 \%$ $\mathrm{CO}_{2}$. Cells were maintained in primary culture for $5-7$ days prior to experiments to maximise secretory capacity.

Catecholamine release from single chromaffin cells was measured using amperometry (Chow et al. 1992). A carbon-fibre electrode (ProCFE, Dagan Corporation, Minneapolis, MN, USA) was carefully placed on an individual chromaffin cell and $+800 \mathrm{mV}$ applied to the electrode under voltage clamp conditions. The current due to catecholamine oxidation at the tip of the electrode was recorded using an EPC-9 amplifier and Pulse software (HEKA Electronic, Lambrecht, Germany), sampled at
$10 \mathrm{kHz}$ and low-pass filtered at $1 \mathrm{kHz}$. For quantitative analysis the Pulse files were converted to Axon Binary Files (ABF Utility, version 2·1, Synaptosoft, Decatur, GA, USA) and the secretory spikes analysed (Mini Analysis, version $6 \cdot 0 \cdot 1$, Synaptosoft, Decatur) for a period of $60 \mathrm{~s}$ from the start of exposure to the various treatments. The total charge released over this $60 \mathrm{~s}$ period was calculated as the average charge of each secretory event multiplied by the number of events within $60 \mathrm{~s}$. The charge (in picocoulombs, $\mathrm{pC}$ ) of a single secretory event is simply the area under each spike (charge is the product of current and time), which is automatically calculated by the Mini Analysis software.

The standard saline contained $(\mathrm{mM}): 140 \mathrm{NaCl}, 5 \mathrm{KCl}$, $2 \mathrm{CaCl}_{2}, 1 \mathrm{MgCl}_{2}, 5$ D-glucose, 10 Hepes ( $\mathrm{pH} \mathrm{7.4).}$ High $\mathrm{K}^{+}$-containing solution was the same as control bath solution except that $70 \mathrm{mM} \mathrm{K}^{+}$replaced an equimolar amount of $\mathrm{NaCl}$. All solutions with or without the addition of activin or cadmium $\left(\mathrm{Cd}^{2+}\right)$ were applied to cells using a gravity perfusion system, the outlet of which was placed within $500 \mu \mathrm{m}$ of the recorded cell. All other reagents were obtained from Sigma-Aldrich. All experiments were carried out at room temperature $\left(22-24^{\circ} \mathrm{C}\right)$.

The equation used for the $\mathrm{EC}_{50}$ calculation and the creation of the sigmoidal dose-response curve was obtained from the graphing and analysis software used (Prism 3·0, GraphPad Software, San Diego, CA, USA) and is as follows:

$$
\mathrm{Y}=\text { Bottom }+\left(\frac{\text { Top-Bottom }}{1+10^{\left(\operatorname{LogEC}_{50}-\mathrm{X}\right) * \text { Hill Slope }}}\right)
$$

where:

$\mathrm{X}=$ the logarithm of concentration

$\mathrm{Y}=$ the response

Bottom $=$ Y-axis value at the bottom plateau

$\mathrm{Top}=\mathrm{Y}$-axis value at the top plateau

Hill slope was calculated to be 6

All data are displayed as mean \pm S.E.M. and data were tested for significant differences using one-way ANOVA for analysis between different groups and Student's paired $t$-test for comparisons within groups. $P<0.05$ was set as the limit for statistical significance.

\section{Results}

A variety of concentrations of activin A were applied acutely to cultured chromaffin cells (Figure 1A). Activin A was found to be without significant effect on secretion, recorded using amperometry, at very low levels $(0 \cdot 1$ and $0.5 \mathrm{nM})$ but secretion reached maximal levels at a concentration of $2 \mathrm{nM}$. This concentration-dependency followed a sigmoidal relationship, enabling an $\mathrm{EC}_{50}$ value of 

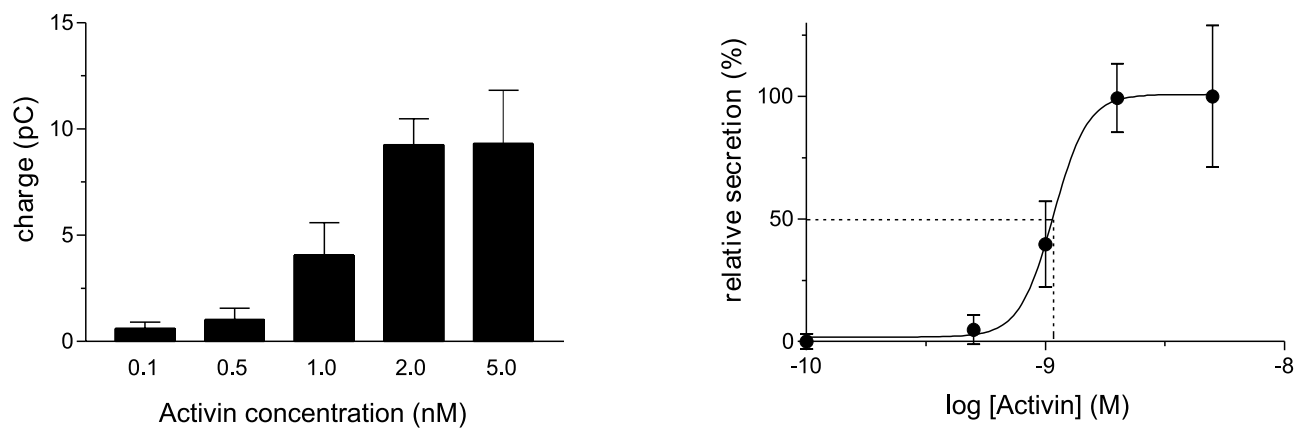

Figure 1 Dose-response effect of activin on catecholamine secretion. Chromaffin cells were exposed to various concentrations of activin for $60 \mathrm{~s}$. Total charge released over this period was evaluated as stated in the Materials and Methods section. The lowest concentration with a maximal effect was $2 \mathrm{nM}$. All data from these figures are from 5-7 cells.

$1 \cdot 1 \mathrm{nM}$ to be calculated (Figure 1B). Given that the minimal concentration of activin that gave maximal response was $2 \mathrm{nM}$, this concentration was used in all subsequent experiments.

All chromaffin cells were tested for their initial secretory capacity by $60 \mathrm{~s}$ exposure to high $\mathrm{K}^{+}(70 \mathrm{mM})$ solution in order to be sure that any cell tested with activin could secrete in response to a known strong stimulus. This induced an immediate and large level of secretion from single cells (Figure 2A), which was completely reversible upon washout with control bath solution $(n=11)$. The application of activin $(2 \mathrm{nM})$ also caused a rapid and substantial response that was reversible upon washout (Figure 2A). Approximately 50\% of cells tested were found to respond to activin $\mathrm{A}$. To test whether the stimulation cased by activin $\mathrm{A}$ induced $\mathrm{Ca}^{2+}$ entry through voltagegated $\mathrm{Ca}^{2+}$ channels, we applied $\mathrm{Cd}^{2+}(200 \mu \mathrm{M})$ to the same cells and then stimulated the cells with activin A in the continued presence of $\mathrm{Cd}^{2+}$. This resulted in a significant reduction in both spike frequency $(P<0 \cdot 05)$ and total charge released $(P<0 \cdot 01)$ when the effect of activin is compared with the same cells in which $\mathrm{Cd}^{2+}$ was present or absent. This loss of secretion in response to activin $\mathrm{A}$ in the presence of $\mathrm{Cd}^{2+}$ indicates that $\mathrm{Ca}^{2+}$ entry through voltage-gated $\mathrm{Ca}^{2+}$ channels is required for activininduced secretion to occur. In some experiments, activin A was applied again after exposure to $\mathrm{Cd}^{2+}$, once $\mathrm{Cd}^{2+}$ had been washed off the cell, and secretion was found to still occur (results not shown). High $\mathrm{K}^{+}$-induced secretion was also blocked by the application of $\mathrm{Cd}^{2+}$ to the bath solution (results not shown).
The total amount of secretion, displayed as charge (a representation of the area under each secretory spike), as well as the frequency of secretory spikes during a $60 \mathrm{~s}$ exposure under all the above experimental conditions were analysed (Figure 2B and C). These results illustrate that activin $\mathrm{A}(2 \mathrm{nM})$ causes a robust level of secretion, which appeared smaller in frequency and magnitude to that caused by $70 \mathrm{mM} \mathrm{K}^{+}$. However, due to the relative variability of these results, there was no significant difference in total charge released of spike frequency between the two groups. These results also show that the presence of $\mathrm{Cd}^{2+}$ significantly reduces activin-induced secretion $(n=4 ; P<0 \cdot 01)$. We also analysed a variety of spike parameters to investigate whether the kinetics of release of secretory vesicles stimulated by activin A alters from that caused by membrane depolarization (i.e. by $70 \mathrm{mM} \mathrm{K}{ }^{+}$ solution). The results of this analysis (Table 1) indicate that none of the spike parameters are different between those caused by stimulation with activin A (254 events from 6 cells) and those induced by $70 \mathrm{mM} \mathrm{K}^{+}$(878 events from 11 cells).

\section{Discussion}

In this report we provide evidence of a new physiological mechanism in which activin A stimulates catecholamine secretion from rat chromaffin cells of the adrenal medulla. This is a physiologically relevant finding given the well established role and presence of the activin A signalling system in the adrenal cortex (Vanttinen et al. 2002,

Table 1 Average spike parameters from all cells exposed to high $\mathrm{K}^{+}(70 \mathrm{mM} ; n=11)$ and activin $\mathrm{A}(2 \mathrm{nM} ; n=6)$

\begin{tabular}{|c|c|c|c|c|c|c|}
\hline & $\begin{array}{l}\text { Frequency } \\
(\mathrm{Hz})\end{array}$ & $\begin{array}{l}\text { Amplitude } \\
(\mathrm{pA})\end{array}$ & $\begin{array}{l}\text { Area } \\
(\mathrm{fC})\end{array}$ & $\begin{array}{l}\text { Half-width } \\
(\mathrm{ms})\end{array}$ & $\begin{array}{l}\text { Rise time } \\
(\mathrm{ms})\end{array}$ & $\begin{array}{l}\text { Decay } \\
\text { time }(\mathrm{ms})\end{array}$ \\
\hline High $\mathrm{K}^{+}$ & $1 \cdot 3 \pm 0 \cdot 3$ & $63 \cdot 2 \pm 9 \cdot 2$ & $214 \pm 23 \cdot 2$ & $4 \cdot 3 \pm 0 \cdot 7$ & $3 \cdot 7 \pm 0 \cdot 5$ & $7 \cdot 0 \pm 1 \cdot 2$ \\
\hline Activin & $0 \cdot 7 \pm 0 \cdot 2$ & $72 \cdot 4 \pm 6 \cdot 6$ & $236 \pm 22 \cdot 3$ & $3 \cdot 9 \pm 0 \cdot 8$ & $3 \cdot 2 \pm 0 \cdot 5$ & $6 \cdot 3 \pm 1 \cdot 1$ \\
\hline
\end{tabular}




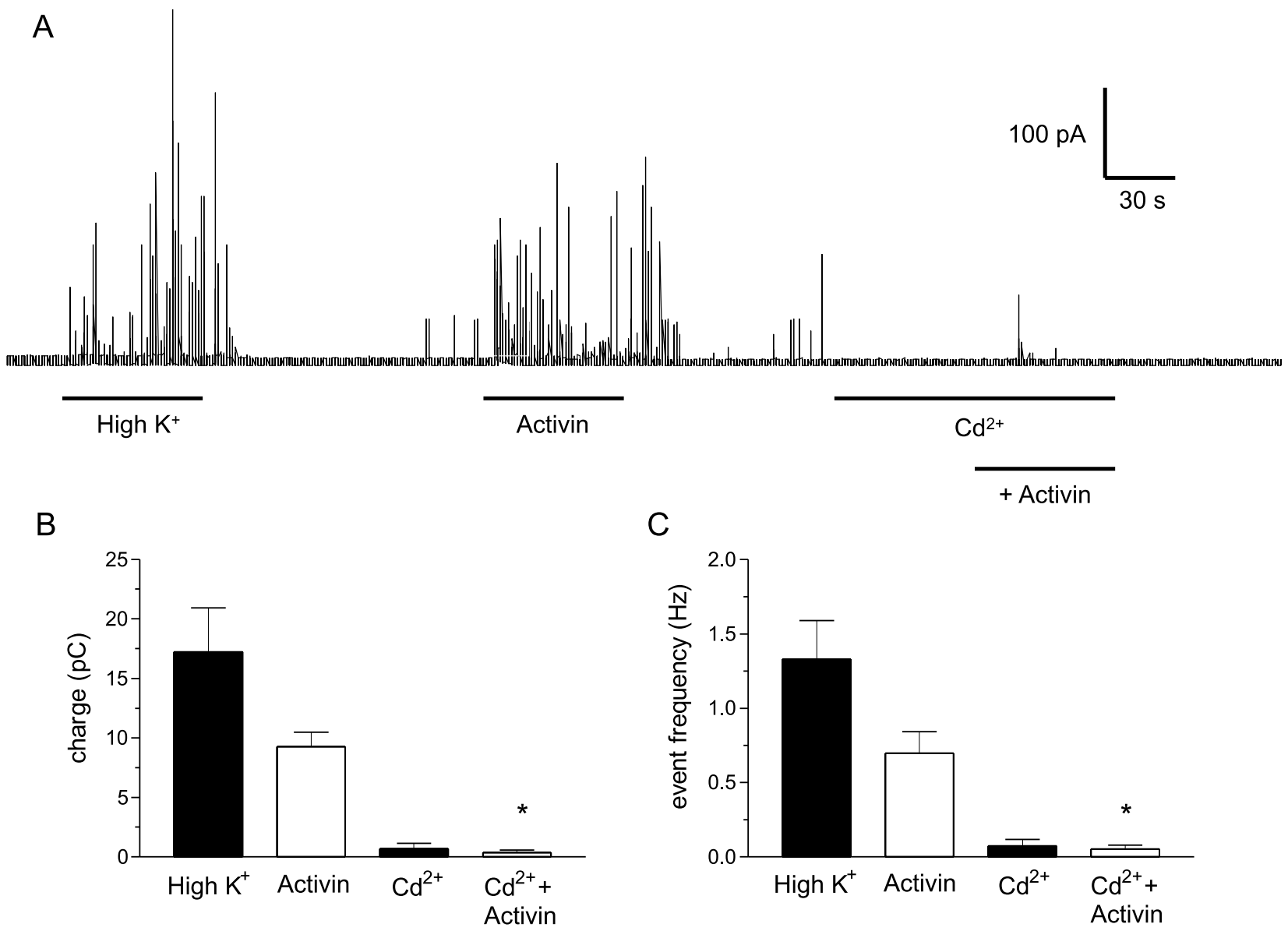

Figure 2 Amperometric detection of catecholamine secretion from a single rat chromaffin cell. (A) Example trace of an amperometry experiment in which a single cell was exposed to $70 \mathrm{mM} \mathrm{K}^{+}$solution, activin $\mathrm{A}(2 \mathrm{nM})$ and activin $\mathrm{A}$ in the presence of $\mathrm{Cd} \mathrm{d}^{2+}(200 \mu \mathrm{M})$. This cell was selected as it displayed a very high response to activin. Spikes indicate release of a single secretory vesicle. Mean ( \pm S.E.M.) results of total charge (B) and frequency of release events (C) when single cells were exposed to various treatments over 60 seconds.

* indicates $P<0.05$ compared with activin group.

Vanttinen et al. 2003). The secretion of activin A from the adrenal cortex suggests that paracrine signalling within the adrenal gland may be adequate to cause activin-induced catecholamine release. In the adrenal gland, most of the cortical blood flows through the medulla (Kikuta \& Murakami 1982), meaning that the chromaffin cells will be exposed to much higher concentrations of activin A than those seen in the whole body circulation. As activin A is also known to be secreted from human pheochromocytomas (Liu et al. 2000), it is plausible that any activin A which might be secreted from chromaffin cells would act in an autocrine manner to induce further catecholamine secretion.

Our results indicate that an activin A concentration of $2 \mathrm{nM}$ is the lowest concentration that gives maximal effects in stimulating catecholamine secretion. This is in close agreement with a previous result showing that the same activin A concentration has significant effects on insulin secretion and ion channel modulation and maximal effects on stimulating $\mathrm{Ca}^{2+}$ influx in doseresponse analysis (Mogami et al. 1995, Fukuhara et al. 1997, Florio et al. 2000).

Previous work has illustrated that the effects of activin A can occur through the manipulation of ion channel function in endocrine cells such as insulin-secreting $\beta$-cells (Mogami et al. 1995) and FSH-secreting tumor cells (Takano et al. 1992, Takano et al. 1994). This new finding that activin A stimulates catecholamine release from chromaffin cells is physiologically important given the many important roles that catecholamines play in homeostatic regulation. These roles include the triggering of the classical 'flight or fight' response, regulation of heart rate and blood pressure as well as fetal survival during episodes of intrauterine stress (Phillippe 1983).

Our results illustrate that the level of catecholamine secretion stimulated by activin A is similar in magnitude to 
that caused by membrane depolarization induced by an increased external $\mathrm{K}^{+}$concentration. This is further reinforced by the similarity in all spike parameters analysed from our experiments. As well as this, $\mathrm{Ca}^{2+}$ entry through voltage-gated $\mathrm{Ca}^{2+}$ channels is required for activininduced secretion based on the fact that the $\mathrm{Ca}^{2+}$ channel antagonist, $\mathrm{Cd}^{2+}$, blocks activin-induced secretion. Thus, activin A seems to cause membrane depolarization as this is required for the opening of these voltage-gated $\mathrm{Ca}^{2+}$ channels. Given that activin A induces catecholamine secretion within approximately 10-30 seconds of being applied, we hypothesize that this secretion is caused either by direct effects of activin A on certain ion channels (such as through the reduced opening of $\mathrm{K}^{+}$channels, for example) or by indirect effects on such channels through a more complex signalling cascade.

This report examines only the end point of the signalling cascade, secretory vesicle exocytosis, within chromaffin cells. Further investigations will need to be carried out to find whether this effect of activin A is caused by ion channel modulation, what intracellular mechanisms are involved in this response and whether other members of the TGF- $\beta$ family cause similar effects to those reported here by activin $A$.

\section{Acknowledgements}

The authors would like to thank Dr Paul Farnworth for the supply of Activin A for these experiments.

\section{Funding}

This work is supported by Australian NHMRC and the TM Ramsay Fellowship award. The authors declare that there is no conflict of interest that would prejudice impartiality.

\section{References}

Bilezikjian LM, Blount AL, Leal AM, Donaldson CJ, Fischer WH \& Vale WW 2004 Autocrine/paracrine regulation of pituitary function by activin, inhibin and follistatin. Molecular and Cellular Endocrinology 225 29-36.

Chow RH, von Ruden L \& Neher E 1992 Delay in vesicle fusion revealed by electrochemical monitoring of single secretory events in adrenal chromaffin cells. Nature 356 60-63.
Florio P, Luisi S, Marchetti P, Lupi R, Cobellis L, Falaschi C, Sugino H, Navalesi R, Genazzani AR \& Petraglia F 2000 Activin A stimulates insulin secretion in cultured human pancreatic islets. Journal of Endocrinological Investigation 23 231-234.

Fukuhara S, Mukai H \& Munekata E 1997 Activin A and all-trans-retinoic acid cooperatively enhanced the functional activity of L-type $\mathrm{Ca}^{2+}$ channels in the neuroblastoma C1300 cell line. Biochemical and Biophysical Research Communications 241 363-368.

Harrison CA, Gray PC, Vale WW \& Robertson DM 2005 Antagonists of activin signaling: mechanisms and potential biological applications. Trends in Endocrinology and Metabolism 16 73-78.

Iwahori Y, Saito H, Torii K \& Nishiyama N 1997 Activin exerts a neurotrophic effect on cultured hippocampal neurons. Brain Research $76052-58$.

Kikuta A \& Murakami T 1982 Microcirculation of the rat adrenal gland: a scanning electron microscope study of vascular casts. American Journal of Anatomy 164 19-28.

Liu J, Heikkila P, Kahri AI \& Voutilainen R 2000 Expression of activin $\mathrm{A}$ and its receptors in human pheochromocytomas. Journal of Endocrinology 165 503-508.

Massague J 1998 TGF-beta signal transduction. Annual Review of Biochemistry 67 753-791.

Mogami H, Kanzaki M, Nobusawa R, Zhang YQ, Furukawa M \& Kojima I 1995 Modulation of adenosine triphosphate-sensitive potassium channel and voltage-dependent calcium channel by activin A in HIT-T15 cells. Endocrinology 136 2960-2966.

Phillippe M 1983 Fetal catecholamines. American Journal of Obstetrics and Gynecology 146 840-855.

Takano K, Yamashita N, Kojima I, Kitaoka M, Teramoto A \& Ogata E 1992 Effects of activin A and somatostatin on intact FSH secretion and intracellular $\mathrm{Ca}^{2+}$ concentration in human FSH-secreting pituitary adenoma cells. Biochemical and Biophysical Research Communications 182 1408-1415.

Takano K, Ogata E \& Yamashita N 1994 Effects of activin A on ionic channels in human FSH-secreting tumour cells. Journal of Physiology 474 65-73.

Vanttinen T, Kuulasmaa T, Liu J \& Voutilainen R 2002 Expression of activin/inhibin receptor and binding protein genes and regulation of activin/inhibin peptide secretion in human adrenocortical cells. Journal of Clinical Endocrinology and Metabolism 87 4257-4263.

Vanttinen T, Liu J, Kuulasmaa T, Kivinen P \& Voutilainen R 2003 Expression of activin/inhibin signaling components in the human adrenal gland and the effects of activins and inhibins on adrenocortical steroidogenesis and apoptosis. Journal of Endocrinology 178 479-489.

Wada M, Shintani Y, Kosaka M, Sano T, Hizawa K \& Saito S 1996 Immunohistochemical localization of activin A and follistatin in human tissues. Endocrine Journal 43 375-385.

Received 19 April 2005

Accepted 23 June 2005

Made available online as an Accepted Preprint 24 June 2005 